Research Article

\title{
Santri Management at Modern and Salafiyah Islamic Boarding Schools
}

\author{
Muhammad Sirajul Munir*, Wahyu, Karyono Ibnu Ahmad \\ Master Program of Education Management, Universitas Lambung Mangkurat, Banjarmasin 70123, Indone- \\ sia
}

Article history:

Submission September 2020

Revised November 2020

Accepted November 2020

*Corresponding author:

E-mail: $\underline{\text { munirabusal- }}$ man@gmail.com

\begin{abstract}
This study aimed to analyze the management of Islamic boarding schools in modern boarding schools and salafiyah boarding schools through aspects of administrative management, recruitment, guidance, supervision, and evaluation. This research was a descriptive study with a qualitative approach. The results of the study showed that the management of the Islamic boarding school in modern Islamic boarding schools and Salafiyah Islamic boarding schools including aspects of (1) Student administrative management through a variety of students' documents. (2) New student recruitment through tahfidz potential, general knowledge of Islam, and psychological test. (3) Guidance for students was done through formal and non-formal education. (4) Supervision of students was conducted in stages from the subordinates to the superiors. (5) Santri evaluation was done through tests and non-tests. Islamic boarding schools should balance coaching between aspects of religious education and aspects of general education and add coaching in the field of technology
\end{abstract}

Keywords: Santri management, Islamic boarding school, modern, salafiyah

\section{Introduction}

An Islamic boarding school is an Islamic educational institution for learning science, especially for religious science. It can be because this time, religion along with governance are important to be controlled in establishing distinctively corporate sociology for global interaction (Smith, 2019). Although some believe that religion and science cannot be united (Carus, 1904), in today's modern era, it is a common thing to study both. Besides, every religion has its character (Krop, 2019), including Islam with its way of teaching, learning, and living. In Indonesia, as the Islamic discourse has developed apace (Machmudi, 2008b), Islamic boarding schools cannot be separated from Muslims' life. It is since the life of religion is on the accurate subjective attitude of its people (Wright, 1912) and on the fact that religion has become visible as part of the public sphere
(Lundby, 2017). Islamic educational institutions were known after the arrival of Islam in Indonesia in the $7^{\text {th }}$ century of the Common Era, but the existence and development started to be popular in the $16^{\text {th }}$ century. Islamic boarding schools had started to be found since then for teaching various classical Islamic books in fiqh, aqidah, and tasawuf; also, they had become Islamic broadcasting centers (Dhofier, 2014:34). Since religion is an institution (Leuba, 1912), the purposes of these institutions were as media for exploring Islam and apply its theory in daily life, which was called as tafaqquh fi al-din. For instance, in Jombang for quite some time, it is called pesantren that is the main institution through which a large number of Islamic societies getting educated (Turmudi, Kiai and the Pesantren, 2006a). Meanwhile, pesantren is the traditional boarding school and madrasah is the modern religious school (Muhaimin, 2006). This pesantren system has been established

How to cite:

Munir, M .S. (2020). Santri management at modern and Salafiyah Islam boarding schools. Journal of K6 Education and Management, 3 (3), 390 - 400. doi: 10.11594/jk6em.03.03.11 
and occurred in parallel in Java that came from the same source (Lanti, Ebih, \& Dermawan, 2019) that has been through the long process of Islamisation that planted its roots in the society of Indonesian archipelago (Machmudi, 2008a) which is different compared to kejawen that had been widespread before (Koentjaraningrat, 1980). Furthermore, in the spirit of the times, the idea of providing better education for Muslim women had also occurred that was embraced by Islamic organizations such Muhammadiyah and NU (Srimulyani, 2012). Thus, it can be seen that Islamic institutions have been through a long journey and showing success.

A factor for the success of an Islamic boarding school can be seen from its students or santri. A santri is input in an Islamic boarding school. The criterion of success is seen from its output. In this process, a new habitus is more or less intentionally learned in connection with some kind of religious realignment (Kupari, 2016). The students will become the new individual or collective trends in reforming Islam (Sardar, Serra, \& \& Jordan, 1019). Hence, the high-quality of the output is impossible to be produced from low-quality input. It goes for the high-quality output must have been also from high-quality input. If the Islamic boarding school aims to enhance its education quality, it has to enhance the quality of its input as the beginning. Despite the school has good input, it is still impossible to be good if the school does not support them with regulations or good management. There are a lot of Islamic boarding schools that have good input but the output is bad. After the cause was examined, the unsuccessful output was caused by bad santri management, not because of the education or teaching materials.

Student or santri management is management activity associated with students from the entry (in the time of enrolling to the school) to the end (until graduation). As supervision (Woodcock, 2017) and leadership (Londoño, Jarvis, Lopoukhine, \& Mapesa, 2015) are important for management, the most common responsibilities in education in normal times are the provision of education, starting a new school, and data collection (Culbertson \& Constant, 2015). In the Islamic context, student management has a similar meaning to santri management (Qomar, 2014: 141) and the leadership is sometimes in the hand of kyai (Turmudi, The Social Reality of Kiaiship, 2006b). Usually, the leader of an Islamic boarding school is both a kyai and a manager (Solahudin, 2008a). Besides, student engagement in their classes and institutions is important (Sotiriou, 2018) as well as a social activity (Barwick, 2010) in the santri life. The characteristics of the leader, the follower, and their patterns of relationships can be seen from the distinctively creative expression of the institutions (Solahudin, 2008b). Hence, it is also important to designing particular kinds of student assignments (Fung, 2017) by knowing the institution's management key principles (Spenceley, et al., 2015) that educators are shaping how santri can get more focused on their study field.

Central Hulu Sungai Regency has two favorite Islamic boarding schools such as Darul Istiqamah Modern Islamic Boarding School and Salafiyah Nurul Muhibbin Islamic Boarding School. They use a boarding system like other Islamic boarding schools that require the santri to stay in the dormitory, so all teachers and santri live in the dormitory together. Automatically, it demands the schools to implement good santri management; as a result, the teaching-learning process in the Islamic boarding schools will be resulting in effectiveness and good quality Islamic boarding schools. Thus, Muslim internal transformation that attempts to maintain the Muslim commitment to the fundamental principles of Islam and to reconstruct an Islamic society in accord with the Qur'an and the Sunnah (Rosyad, 2006) can be achieved through good Islamic boarding school management.

As two favorite Islamic boarding schools, Darul Istiqamah and Salafiyah Nurul Muhibbin have a continuously growing number of santri. The preliminary research found that the characteristics of each boarding school had become the attraction for society to choose Islamic boarding schools as places for their children to learn.

Based on pre-observation and preinterview, it was found that the Islamic education foundation of Darul Istiqamah 
managed some other educational foundations such as MI Plus Darul Istiqamah, Madrasah Tsanawiyah Darul Istiqamah, Madrasah Aliyah Darul Istiqamah, and Darul Istiqamah Vocational High School. Salafiyah Nurul Muhibbin still applied salafiyah tradition. The Santri were grouping based on the classical Islamic books they learned. This Islamic boarding school used a grammar-translation teaching method. The schools still maintained the salaf tradition for the mindset and educational system rigorously by protecting the traditional authenticity and the value of the school either in symbolization or substance. The teaching materials were Classical books. Moreover, the preliminary research revealed that the santri management of both Islamic boarding schools was not optimally operated because the management was only focused on new santri and current santri, whereas there was no attention for alumni who had graduated from the schools.

Concerning the urgency of the santri management in managing an Islamic boarding school, Istiqomah (2012) stated that every educational institution, including an Islamic boarding school, was insisted to give good services to the customers. To make it possible, the school needs good management support. The santri management is an effort to manage santri, starting from the moment they register to the school until they graduate. The implementation of santri management has a crucial role in gaining a better quality of the santri and Islamic boarding school. Saidi (2016) mentioned that santri management had a purpose to find out the new santri recruitment, selection, placement, training and guidance, and alumni supervision.

\section{Material and Methods}

This research was field research. It was a descriptive research with a qualitative approach. Field research is a methodological approach to observe behavior under natural conditions (Reyes-García \& Sunderlin, 2011). Usually, the field research has a team to do the research (Fielding, et al., 2015). It is begun with the institutional aspects which guide the implementation of the field research (Sunderlin, et al., 2010); (Tessama, Davis, Tella, \& Lambe, 2013). The study is usually strengthened by its examination of the entire community and its social institutions along with its assessment of community values and daily life (Baker, 1995). The field research has valid data compared to just citing each other's work or researchers (Dolnik, 2011).

Qualitative methods enable the collection of data by observation through the researcher's participation in the investigations; to show the purpose of the analysis, the most relevant data is used for a deeper investigation (Juloux, 2018). Qualitative methods such as interviews and focus groups, as well as participant observations, have the potential to play integral roles for all academic endeavors in terms of the formulation of questions, building operational definitions, and designing research instruments (Atkinson, 2017). Using this approach, the study of social processes or the reasons behind human behavior can be conducted (Stenius, Mäkelä, Miovský, \& Gabrhelík, 2017).

This study was conducted on two Islamic boarding schools in Central Hulu Sungai Regency: Modern Darul Istiqamah and Salafiyah Nurul Muhibbin. It used primary data from observations and interviews, and secondary data from documentations. The data were analyzed qualitatively using a single and multi-site data analysis method.

\section{Results and Discussion \\ Santri administrative management at Darul Istiqamah Modern Islamic Boarding School and Nurul Muhibbin Salafiyah Islamic Boarding School in Central Hulu Sungai Re- gency}

Santri administrative management was a crucial function in gaining the ease of the activities. The activities were done by organizations and other institutions. Santri management was an activity to record the santri from its enrollment to its graduation. However, not all regulations related to santri were managed by santri management.

Santri administration in every Islamic boarding school including at Darul Istiqamah Modern Islamic Boarding School and Nurul Muhibbin Salafiyah Islamic Boarding School in 
Central Hulu Sungai Regency must be done well because santri administration was closely related to santri's data in every Islamic boarding school.

The implementation of santri administration at Darul Istiqamah Modern Islamic Boarding School and Nurul Muhibbin Salafiyah Islamic Boarding School in Central Hulu Sungai Regency had started since the beginning of new students' enrollment in every new school year. It was compatible with the interview with the head of Darul Istiqamah Modern Islamic Boarding School who stated that santri administration at the school including all the processes from enrollment to graduation. There were some documents as part of santri administration such as sourcebooks, registration books, administration books for financial, school fees or infaq, santri in risk administration, guidance and counseling administration, school transfer or dropped out, reports, and personality records, presence list, permit notes for going out the boarding /going home /umrah, hajj, and et cetera. The santri administrative management was correlated to the data collected from the enrollment. In the new santri registration, the prospective santri must bring some published requirements such as registration forms, copies of graduation certificates, photos, and many more.

From the interview, the researcher found that santri's data at Darul Istiqamah Modern Islamic Boarding School and Nurul Muhibbin Salafiyah Islamic Boarding School were collected through re-registration. Darul Istiqamah Modern Islamic Boarding School collected the data manually and online, but Nurul Muhibbin Salafiyah Islamic Boarding School merely collected the data manually.

According to the result of the interviews, the santri administration at Darul Istiqamah Modern Islamic Boarding School and Nurul Muhibbin Salafiyah Islamic Boarding School could be identified from their documents including sourcebooks, registration books, administration books for financial, school fees or infaq, santri in risk administration, guidance and counseling administration, school transfer or dropped out, reports, and personality records, presence list, permit notes for going out the boarding /going home /umrah, hajj and any other.

The santri administrations were including various documents like sourcebooks, registration books, administration books for financial, school fees or infaq, santri in risk administration, guidance and counseling administration, school transfer or dropped out, reports, and personality records, presence list, permit notes for going out the boarding /going home /umrah, hajj and any other.

\section{The new santri recruitment at Darul Istiqamah Modern Islamic Boarding School and Nurul Muhibbin Salafiyah Islamic Boarding School in Central Hulu Sungai Re- gency}

The new santri recruitment was a searching process, deciding, and attracting a competent new santri at the school. Based on that thought, Darul Istiqamah organized some committees for the admission stage. These committees had duties to do everything related to the recruitment of good santri. Before carrying out the admission process, the committees determined the school's capacity or the total number of new santri. The santri recruitment was the very first stage in the new school year. It was also done by Darul Istiqamah Modern Islamic Boarding School and Nurul Muhibbin Salafiyah Islamic Boarding School at Central Hulu Sungai Regency. These recruitments were including the planning of the total number of new santri, method of selection, grouping, and placement, tuition fee, orientation, and list of committees.

The head of the schools said that there was a different recruitment system between Darul Istiqamah Modern Islamic Boarding School and Nurul Muhibbin Salafiyah Islamic Boarding School. Darul Istiqamah Modern Islamic Boarding School had more stages because the prospective santri must go through three stages of selection such as Tahfidz potential (Reciting and writing and tahfidz of the Holy Qur'an), General Islamic Knowledge, and psychological test. Whereas, there was only reciting and writing of the Holy Qur'an stage for the recruitment at Nurul Muhibbin Salafiyah Islamic Boarding School.

The enrollment of the new or transferred santri must be administered well. For the new 
santri, they had a requirement to fill a form containing name, address, previous education, parents' profiles, parents' occupations, and others. Whereas, for the transferred santri, they did not only fill in the form but also attach the transferred letter from the previous school. The purpose of this requirement was to confirm that the santri transferred because of problems or not. After filling in the provided form, at Salafiyah boarding school including at Nurul Muhibbin, santri were immediately registered and could join all the activities at the school. It was different at Darul Istiqamah Modern Islamic Boarding School which required the santri to take the entrance examination for measuring their ability and the level of education (their placement).

This research showed that the planning was running well by discussing and accommodating all suggestions for making discussion, managing admission committees, determining the capacity, deciding the requirements, and selecting the candidates, so the planning could run smoothly like it was expected, even if not all could go perfectly because of some reasons. The planning needed certainty or clarity to make every objective could be done well.

According to those interviews, it could be concluded that planning was a basic process done before work. In this research, a basic process was a process that aimed to determine the outline of the vision, the mission (operation procedure), and the policy. Also, planning was a basic process in which the leader decided on a vision and mission.

The planning stage in the new santri recruitment, both at Darul Istiqamah Modern Islamic Boarding School and Nurul Muhibbin Salafiyah Islamic Boarding School in Central Hulu Sungai Tengah Regency, was in line with the previous research conducted by Hamid (2012) who said that the planning was involving need analysis of the students for determining the students' capacity by considering the number of available classes, teachers and facilities. The new recruitment was done after managing a list of committees for the admission process. As it previously mentioned, the santri recruitment at Darul Istiqamah Modern Islamic Boarding School was done in two ways, offline and online. Moreover, there were also three stages of tests: the test of Tahfidz potential (reciting and writing, dan tahfidz of Holy Qur'an), general Islamic knowledge, and psychological test. It indicated that Darul Istiqamah Modern Islamic Boarding School used technology to enhance its education quality and also its recruitment system. This research was also in line with the research by Suhaimi (2015) who mentioned the principle of using learning resources to access necessary knowledge and skills.

The system approach principle was a system of implementation in education and learning that was designed by the system approach. As a result, the learning process would be more focused, effective, and efficient, because it was through some certain stages starting from analysis to evaluation. Moreover, the use of technology makes the learning process also became more innovative, flexible, and various because it used a lot of learning sources in different educational media which were applicable anytime and anywhere to facilitate every student to find information and skills they needed (Hamda \& Dalle, 2011; Dalle, Haderani, \& Ulfah, 2010). The new santri recruitment at Nurul Muhibbin Salafiyah Islamic Boarding School in Central Hulu Sungai Regency was conducted manually and the selection process only contained a stage of reciting and writing of Holy Qur'an.

This research was in line with Saidi's (2016) research which mentioned the process of new santri recruitment could be successful if there was planning; socialization and obvious procedures; management, committee, implementation, documents verification, entrance test, and supervision; training new santri after place them based on the test result.

The santri's training at Darul Istiqamah Modern Islamic Boarding School and Nurul Muhibbin Salafiyah Islamic Boarding School in Central Hulu Sungai Regency.

Training and guiding had a mission to help all santri without exception to develop their potentials optimally, having self-awareness, and gaining happiness. The meaning of guidance appropriate to Islamic belief was stated in $\mathrm{Al}$ Qur'an and Hadits of Prophet Mohammed, in which an Islamic boarding school was a santri's 
second parents. From Islamic belief, it was known that parents were receiving responsibility for a child, and then they entrusted the child to an Islamic boarding school that accepted him or her.

Darul Istiqamah Modern Islamic Boarding School had integrated training for the santri by combining formal and non-formal education. A training through formal education was managed by Tsanawiyah, Aliyah, and Vocational High Schools. Whereas, training through nonformal education was managed by supporting activities such as religious training and extracurricular activities.

It was different from Nurul Muhibbin Islamic Boarding School which was a salafiyah boarding school. Educational and teaching activities at Nurul Muhibbin Salaf Islamic Boarding School were managed by the traditional teaching method. The traditional teaching method was a teaching method used by ustad using wetonan method (Bandongan), sorogan, muzakarah (memorization). It was because this institution that was established in August 1999 had a position as a salaf educational institution or an original salaf Islamic boarding school teaching Islamic classical books written in Arabic which was known as the yellow book (Kitab Kuning). The teaching method at Nurul Muhibbin Islamic Boarding School used oldstyle teaching methods by completing main references of Islamic classical books for each subject. So, the standard of learning success was on the completion of all learned classical books, not on the complete understanding of a topic (maudu'). The teaching methods like sorogan, bandongan, and muzakarah was used at this salaf Islamic boarding school. In bandongan method, while a teacher, kyai or ustad was reciting and explaining the content in the books, the santri were listening, understanding, and accepting. In sorogan method, the santri gave a sorog (book) that would be discussed. The teacher listened and gave some necessary comments and guidance. Last, muzakarah method was a memorization method done by the santri independently. Even though Nurul Muhibbin Salaf Islamic Boarding School used those teaching methods, it did not limit the santri to explore deeper about the teaching materials. The santri were given chances to ask, discuss, and talk to ustadz.

The formal education characteristic at Darul Istiqomah Modern Islamic Boarding School could be seen from its learning period limitation. The limitation was in the form of the semester, quadrimester, trimester, or a year. The names in each subject could be different such as marhalah, fashal, thabaqah and sanah. However, the average time needed for each santri to accomplish and mastery of the materials could be varied, especially if there was a special examination. It also depended on the head of the school, ustad, and teachers. It could be three or six years or depended on the formal institution held by the school. Some Islamic boarding schools that managed school educational activities had leveled the study of Islamic classical books, either based on its classical level in formal education or based on the level of ability to study the book. Sometimes, the students were in a higher class, but in the study of classical books, they were still categorized at the basic level. Whereas, at Salafiyah Islamic boarding school, it usually had a congregation study (pengajian). This study was not limited to times and levels. The completion of the study was if the student thought it was enough or the kyai thought the student had learned enough and had enough knowledge of Islam.

An Islamic boarding school that did not provide formal education, such as Nurul $\mathrm{Mu}-$ hibbin Salafiyah Islamic Boarding School also taught classically and gradually. It also based on the time limit as done by khalafiyah Islamic boarding school. In this context, Nurul Muhibbin taught classically. The study period in this boarding school was divided into two categories: First, for male santri took seven years containing Tahdhiry class in the first year for only a year, and six years of first grade to sixth grade. After completing seven years, a santri who wanted to teach religious studies could add $\mathrm{Ta}$ khassus class for a year. Second, female santri had four years of study containing Tahdhiry class in the first year, continued to first grade until third grade. However, it was still possible and allowed if a santri wanted to stay and continue to learn more and deeper. At that moment, the santri studied and recited with kyai and ustad congregationally in the classroom. 
Due to all santri were from various schools (elementary or high school), they had different learning capacities and understanding level. Therefore, the time limitation was flexibly determined by the Islamic boarding school by not limiting the santri who wanted to continue their study or exceed the limit of study.

Darul Istiqamah Modern Islamic Boarding School and Nurul Muhibbin Boarding School emphasized the attitudes of the santri to create santri who had Islamic belief attitudes. It was in line with an opinion (Afifah et al., 2019) that mentioned the implementation of a document curriculum concept into the teaching-learning process. The teaching was designed by following the curriculum guidelines, academic calendar, themes, learning schedules, and daily activities. The organization was managed by making the structure of organizations and daily task divisions. The method used for teaching was the discovery learning method known as by'talqiyyan fikriyyan'a which integrated all fields of study into Islamic belief. The form of control was supervision. The learning evaluation used other supplement books or diaries. Some factors that influence curriculum implementation were teachers, parents, students, environments, and governments.

Darul Istiqamah Modern Islamic Boarding School was better than Nurul Muhibbin Islamic Boarding School because it had extracurricular activities to develop the santri's interests and aptitudes. This was in line with the interview to the head of Darul Istiqamah who mentioned that the school trained the santri's interests and aptitudes through various extracurricular activities such as tahfidz of holy Qur'an, tilawah, arts, marching band, martial arts, courses, sports, languages, maulid al-habsy and scout. According to documentation, the coaches of activities at Darul Istiqamah and Nurul Muhibbin Islamic Boarding School consisted of the head/founder of the school, the caretakers, ustad, outside teachers, and members of OPPM. Ustad and members of OPPM had double functions. The ustadz were not only divided into some divisions, but also responsible to be room guardians, assistants of room guardians, homeroom teachers, and assistants of homeroom teachers. Whereas, the members of OPPM were responsible as the heads of the room or only responsible for their division. All of them had roles in the santri's training process in the aspect of religious responsibility and attitudes.

There was a great difference between educational vision at traditional Islamic boarding schools and at formal education institutions. At traditional Islamic boarding school, the vision and main orientation of the education were to create complete, integrated, and kaffah personalities. The purpose of education was not to fill the students with facts but to prepare them to live cleanly, purely, and sincerely. Educational activities tried to give knowledge and its application. In other words, the main vision of education at traditional Islamic boarding school was to establish humans with faith, knowledge, righteous deed, and good moral. It was different from the vision of education at formal education which intended to establish a certain skill or a job specialization but ignoring ethical and moral values. The different vision and orientation caused the difference in teaching materials and methods.

Finally, it could be concluded that the santri's training and guidance at Darul Istiqamah Modern Islamic Boarding School were managed through formal and non-formal education. Formal education was done through Tsanawiyah, Aliyah, dan Vocational schools, whereas non-formal education was from additional activities in the form of religious guidance and extracurricular activities. The santri's training and guidance at Nurul Mihibbin Salafiyah Islamic Boarding School were managed through wetonan method (Bandongan), sorogan, and muzakarah (memorization) with theory in the legendary yellow books (Kitab Kuning).

The coaching was a conscious, planned, organized, directed, and responsible effort to develop personalities ant all of the aspects. The coaching was in the form of guidance, sharing information, stimulation, persuasion, supervision, and control to create situations where the students could be assisted to develop their positive aptitudes and control their low instincts so that the good manners would be established. According to that opinion, it could be concluded 
that training or coaching was a learning process of helping a person who in the process to fix and develop the knowledge effectively for better results and happiness in the world and afterlife.

In another research (Sarbaini, 2012) was also mentioned that the success of training was also supported by the development of students' obedience; the free space for activities and expression; the class position that oriented to order, calmness, respect, responsibility, and role models; banners and any writing containing the motivation on faith, piety, honored attitudes, achievements, creativity, innovation, autonomy, and discipline; a set of tools to trigger respect and being neat, clean, orderly and gendered.

Suhaimi (2016a) said that teachers should implement a teaching strategy oriented to students to explore the meaning of an event. The paradigm which placed the teachers as the center of education and the students as the objects must be changed by positioning the students as the subjects who actively learn to build understanding by connecting previous experience to new experience. Based on it, the new solutions must be focused on the students' capability for creating innovation. Thus, it was not teachers who did the innovations but students with the teachers' guidance. In certain cases, students as new generations had more passion to recreate progressive innovation than teachers who usually maintained their status quo.

This research also supported Saidi's research (2016) that found the training for santri was done through both curricular and extracurricular. Curricular activities involved salafiyah program to learn yellow books (kitab kuning) and regular nine-year program equivalent to MTs, and packet C program equivalent to high school. These two programs were done simultaneously in a lesson schedule by including a general subject every day. Extracurricular activities were done before midday praying by listening to religious motivations, reciting holy Qur'an, Juz 'Amma, asmaul husna, reading Al Jurumiyah book, practicing lectures or sermons, learning how to be an imam, and learning initiatively at the teachers' houses or courses outside the school.
These results were also in line with the research (Suriansyah et al., 2017) that mentioned two influential aspects such as the school's condition and the kyai who managed well in their field of studies. Moreover, the freedom to learn religion, academics, and subjects were interesting aspects considered by the students to study at the schools.

\section{The santri supervision at Darul Istiqamah Modern Islamic Boarding School and Nurul Muhibbin Salafiyah Islamic Boarding School in Central Hulu Sungai Regency.}

Supervision (controlling) was a systematic effort for creating standard performance appraisal aimed at the planning, design of information feedback system, comparison of actual performance and standard performance, deviation capacity and significance, and necessary actions to guarantee all the resources used efficiently and effectively to reach organization's targets. Supervision was a discovery and implication to equip all the plans done as determined.

The santri supervision system at Darul Istiqamah Modern Islamic Boarding School was a system from subordinates to superiors. It was from the room chairperson, the room coordinators, the santri department, the caretakers, and the headmaster. This system was started from the room chairperson who supervised both inside or outside activities. If a santri had done a mistake, the chairperson would report it to the room coordinator. If the room coordinator could not handle it, the coordinator would report to the santri department. If it still could not be handled, it would be continued to the caretakers, and the last it would be reported to the head of the school.

According to the interview with a caretaker at Darul Istiqamah Modern Islamic Boarding School, the supervision to the santri was still not high enough. Even if the caretakers stayed at the school, trained them directly, and had a responsibility to check the santri's presence in their activities; they still had low responsibility and accuration which caused the obstructed function of the supervision. Supervision at Darul Istiqamah was control to do all activities, especially for the santri's discipline. Supervision was the responsibility 
of all management even if it was an urgent responsibility for the people in the division of security. However, teamwork was important for an organization to achieve the organization's objectives maximally. It was supported by an opinion (Suhaimi, 2016) that said supervision was an effort to bring a secure and orderly school environment with high effectiveness.

The system of supervision for the discipline including (1) Indirect supervision such as (a) making oral reports, (b) written reports, and (c) special reports. (2) Direct supervision such as watching the santri through CCTV.

In other words, supervision at Darul Istiqamah Modern Islamic Boarding School was started from each room chairperson; if there was a santri making any mistake the chairperson would report to the room coordinator; if it still could not be solved, the santri department or security would handle it; then it would be continued to the caretakers; and finally, it would be reported to the head of the school. For example, every responsible division gave attention to every new and old santri. If any of them disobeyed the rules, the sanctions would be given. And nobody was allowed to punish the santri without following the procedures for subordinates to superiors.

The interview also showed that the santri supervision at Nurul Muhibbin Islamic Boarding School involved all divisions and teachers. The supervision was also done through CCTV placed at the school and the school's code of conduct as the guide to the santri's behavior.

The implementation of the school's code of conduct was supervised by all divisions and teachers. The santri who disobeyed the rules would be called by coordinators or other divisions to get sanctions, warnings, or punishment for learning or dropping out. If the santri was rejected with the sanctions, he/she could ask for alleviation from the coordinator, but if the coordinator was refused, the santri had to accept the sanctions as the santri of Nurul Muhibbin Islamic Boarding School.

In a conclusion, the santri supervision at Darul Istiqamah and Nurul Muhibbin was different. The supervision at Darul Istiqamah
Modern Islamic Boarding School was done in a staged system from subordinate to superior (from the room chairperson to room coordinator, to the santri department, to caretaker, and the last to the head of the school). Whereas, the santri supervision at Nurul Muhibbin Salafiyah Islamic Boarding School involved all divisions and teachers. The supervision was also done through CCTV and the school's code of conduct. The supervision was a discovery and implementation of tools to guarantee the implementation was suitable to the planning. It was also in line with research conducted by Istiqomah (2012) who mentioned supervision at Islamic boarding schools had some obstacles that could influence the implementation and supervision such as its facilities and performances of all divisions at the schools.

\section{The santri evaluation at Darul Istiqamah Modern Islamic Boarding and Nurul Muhib- bin Salafiyah Islamic Boarding School in Cen- tral Hulu Sungai Regency}

There was an evaluation of the santri in every Islamic boarding school, which could be done anytime, every day, every week, every month or every year. The ways of evaluation could be varied; it could be in the form of written tests, oral tests, or daily behavior observations.

The head of Darul Istiqamah Modern Islamic Boarding School said that the evaluation was applied to the santri's activities, the same evaluation as formal and non-formal education such as doing oral or written examination at the end and mid of semester. Whereas, the head of Nurul Muhibbin Salafiyah Islamic Boarding School said that evaluation for the santri was through written examination, reciting books, and others.

The evaluation was done in the middle and last semester to find out whether the materials had been mastered or not. The ustad was considered failed if the santri were not competent enough. Consequently, the planning and the implemented activities would be revised for enhancing the santri's competence in their learning.

The santri's daily activities were evaluated through CCTV, so the murabbi could directly 
supervise the santri and ustad in the school to avoid any neglectfulness from the santri or the ustad. The whole evaluations would be done at the end of the semester.

The interviews showed that Darul Istiqamah dan Nurul Muhibbin Islamic boarding schools had planned at the very beginning of the santri's enrollment, this evaluation was done based on the school year by conducting oral and written examinations.

It was in line with Daryanto (2017) who said that educational evaluation was an assessment activity in educational activities through test and non-test which had the function to choose and determine the upgrade level of the santri.

\section{Conclusion and Recommendation}

The santri administrative management at Darul Istiqamah Modern Islamic Boarding School and Nurul Muhibbin Salafiyah Islamic Boarding School could be seen from their documents such as source books, registration books, administration books for financial, school fees or infaq, santri in risk administration, guidance and counseling administration, school transfer or dropped out, reports, and personality records, presence list, permit notes for going out the boarding /going home /umrah, hajj, etc.

The new santri recruitment at Darul Istiqamah Modern Islamic Boarding School was conducted in two ways by being offline (manually) and online. It had three kinds of tests including Tahfidz potential (reciting and writing dan tahfidz of holy Qur'an), general Islamic knowledge and psychological test. Whereas, the new santri recruitment at Nurul Muhibbin Salafiyah Islamic Boarding School in Central Hulu Sungai Regency was merely conducted manually with a stage of test involving reciting and writing the Holy Qur'an.

The santri's training at Darul Istiqamah Modern Islamic Boarding School was done through formal and non-formal education. The training through formal education was conducted in education at Tsanawiyah, Aliyah, and vocational schools. The training through nonformal education was conducted in supplementary activities in the form of religious guidance and extracurricular activities. Meanwhile, the santri's training at Nurul Muhibbin Salafiyah Islamic Boarding School was done traditionally using wetonan method (Bandongan), sorogan, and muzakarah (memorization) with the materials from kitab kuning.

The santri supervision at Darul Istiqamah Modern Islamic Boarding School was done in stages from subordinates to superiors. This supervision was conducted by the room chairperson, the room coordinators, the santri department, the caretakers, and the head of the school. The santri supervision at Nurul Muhibbin Salafiyah Islamic Boarding School involved all the divisions and teachers. The supervision was also conducted through CCTV and the code of conduct of the school for the santri's behavior guidelines. The santri evaluation at Darul Istiqamah Modern Islamic Boarding School and Nurul Muhibbin Salafiyah Islamic Boarding School had been planned since the beginning. This evaluation was done based on the school year by making oral and written examinations.

In the aspect of guidance of students, Islamic boarding schools should balance the coaching between aspects of religious education and aspects of general education and add coaching in the field of technology. Thus, students who graduate later from Islamic boarding schools do not only have high religious knowledge and general knowledge but also have skills in utilizing technology and information.

\section{Acknowledgment}

The researcher realized that this research could be finished because of the help of others, directly or indirectly. Therefore, the researcher was very thankful for all people who had helped for finishing this research.

\section{References}

Atkinson, J. (2017). Qualitative methods. In Journey into Social Activism: Qualitative Approaches (pp. 65-98). New York: Fordham University Press.

Baker, R. (1995). Overview of field research and theoretical models. In Dos Mundos: Rural Mexican Americans, Another America (pp. 1-22). University Press of Colorado.

Barwick, R. (2010). Student activities. In R. M. (Eds.), Geology at ANU (1959-2009): Fifty years of history and reminiscences (pp. 141-160). ANU Press. 
Carus, P. (1904). Definition of religion. The Monist, 14(5) , 766770.

Culbertson, S., \& Constant, L. (2015). Management. In Education of Syrian Refugee Children: Managing the Crisis in Turkey, Lebanon, and Jordan (pp. 29-48). RAND Corporation.

Dalle, J., Haderani, \& Ulfah, R. (2010). The influence of interest, teachers, facilities and infrastructure, on the ability of students to calculate the volume and area of the geometry. Darul Ulum: Junal Ilmiah keagamaan, Pendidikan, dan Kemasyarakatan, 5(10), 3-24.

Dolnik, A. (2011). Conducting field research on terrorism: a brief primer. Perspectives on Terrorism, 5(2), 3-35.

Fielding, M., Davis, M., Weitz, N., Cummings-John, I., Hickey, A., Johnson, F., \& . . Sun, M. (2015). Agricultural investment and rural transformation: A case study of the Makeni bioenergy project in Sierra Leone (pp. 20-34, Rep.). Stockholm Environment Institute.

Fung, D. (2017). Outward-facing student assessments. In Connected Curriculum for Higher Education (pp. 101-117). London: UCL Press.

Hamda, S., \& Dalle, J. (2011). Relationship between service quality and satisfaction in distance learning unit program Indonesia Open University Banjaramsin. Asian Association of Open Universities Annual Conference (AAOU) (pp. 1-6). Penang: Asian Association of Open Universities .

Istiqomah, I. (2012). Implementasi manajemen kesantrian di Pondok Pesantren Al-Hikmah Wayhalim Kedaton Bandar Lampung.

Juloux, V. (2018). A Qualitative approach using digital analyses for the study of action in narrative texts: KTU 1.1-6 from the Scribe 'Ilimilku of Ugarit as a Case Study. In G. A. Juloux V., CyberResearch on the Ancient Near East and Neighboring Regions: Case Studies on Archaeological Data, Objects, Texts, and Digital Archiving (pp. 151-193). Leiden; Boston: Brill.

Koentjaraningrat. (1980). Javanese terms for god and supernatural beings and the idea of power. In S. J. Schefold R., Man, Meaning and History: Essays in Honour of H.G. Schulte Nordholt (pp. 127-139). Brill.

Krop, H. (2019). From religion in the singular to religions in the plural: 1700, a Faultline in the Conceptual History of Religion. In S. J. (Eds.), Enlightened Religion: From Confessional Churches to Polite Piety in the Dutch Republic (pp. 21-59). Leiden; Boston: Brill.

Kupari, H. (2016). Lifelong religion and change. In Lifelong Religion as Habitus: Religious Practice among Displaced Karelian Orthodox Women in Finland (pp. 134-153). Leiden; Boston: Brill.

Lanti, I., Ebih, A., \& Dermawan, W. (2019). Examining the growth of islamic conservatism In Indonesia: The case of West Java. S. Rajaratnam School of International Studies.
Leuba, J. (1912). The definition of religion: À propos of Mr. W. K. Wright's Definition. The American Journal of Theology, 16(4), 642-645.

Londoño, J., Jarvis, J., Lopoukhine, N., \& Mapesa, M. (2015). Leadership and executive management. In L. M. Worboys G., Protected Area Governance and Management (pp. 353380). ANU Press.

Lundby, K. (2017). Public religion in mediatized transformations. In L. H.-J.-G. Engelstad F., Institutional Change in the Public Sphere: Views on the Nordic Model (pp. 241-263). Berlin/Boston: De Gruyter.

Machmudi, Y. (2008a). Jemaah Tarbiyah and Islamisation in Indonesia. In Islamising Indonesia: The Rise of Jemaah Tarbiyah and the Prosperous Justice Party (PKS) (pp. 5180). ANU Press.

Machmudi, Y. (2008b). The emergence of the new santri in Indonesia. In Islamising Indonesia: The Rise of Jemaah Tarbiyah and the Prosperous Justice Party (PKS) (pp. 2150). ANU Press.

Muhaimin, A. (2006). The transmission of religious traditions: The role of pesantren. In The Islamic Traditions of Cirebon: Ibadat and Adat Among Javanese Muslims (pp. 203-246). ANU Press.

Reyes-García, V., \& Sunderlin, W. (2011). Measuring livelihoods and environmental dependence: methods for research and fieldwork. Center for International Forestry Research.

Rosyad, R. (2006). Conclusion: continuation of TAJDID Tradition. In a quest for true Islam: A study of the Islamic resurgence movement among the youth in Bandung, Indonesia (pp. 7780). Canberra: ANU Press.

Saidi. (2016). Manajemen kesantrian pada Pondok Pesantren Salafiyah Nurul Janah Banjarmasin.

Sardar, Z., Serra, J., \& \& Jordan, S. (1019). Islam and religious thought. In Muslim Societies in Postnormal Times: Foresights for Trends, Emerging Issues and Scenarios (pp. 102-105). International Institute of Islamic Thought.

Smith, H. (2019). Religion. In P. W. (Eds.), The Corporation as a protagonist in global history (pp. 137-162). Leiden; Boston: Brill.

Solahudin, D. (2008a). The leader, the followers, and the pattern of relationships. In The Workshop for Morality: The Islamic Creativity of Pesantren Daarut Tauhid in Bandung, Java (pp. 41-60). ANU Press.

Solahudin, D. (2008b). Creative expression eschatological and worldly orientations. In the workshop for morality: The islamic creativity of Pesantren Daarut Tauhid in Bandung, Java (pp. 61-76). ANU Press.

Sotiriou, M. (2018). Investigating student perceptions of student-staff partnership. In T. V. Sotiriou M., Shaping 
Higher Education with Students: Ways to Connect Research and Teaching (pp. 53-63). London: UCL Press.

Spenceley, A., Kohl, J., McArthur, S., Myles, P., Notarianni, M., Paleczny, D., \& Pickering, C. (2015). Visitor management. In L. M. Worboys G., Protected Area Governance and Management (pp. 715-750). ANU Press.

Srimulyani, E. (2012). Women and Pesantren education: history, kinship, and contents. In Women from Traditional Islamic Educational Institutions in Indonesia: Negotiating Public Spaces (pp. 37-62). Amsterdam: Amsterdam University Press.

Stenius, K., Mäkelä, K., Miovský, M., \& Gabrhelík, R. (2017). How to write publishable qualitative research. In S. K., M. M., B. T., P. R., O. J., \& \&. C. (Eds.), Publishing Addiction Science: A Guide for the Perplexed (pp. 155-172). London: Ubiquity Press.

Sunderlin, W., Larson, A., Duchelle, A., Sills, E., Luttrell, C., Jagger, P., \& . . . Ekaputri, A. (2010). Technical guidelines for research on REDD project sites (pp. 76-106, Rep.). Center for International Forestry Research.

Tessama, Z., Davis, M., Tella, P., \& Lambe, F. (2013). Mainstreaming sustainable energy access into national development planning: The case of ethiopia (pp. 14-16, Rep.). Stockholm Environment Institute.

Turmudi, E. (2006a). Kiai and the Pesantren. In Struggling for the Umma: Changing Leadership Roles of Kiai in Jombang, East Java (pp. 21-42). ANU Press

Turmudi, E. (2006b). The social reality of kiaiship. In Struggling for the Umma: Changing Leadership Roles of Kiai in Jombang, East Java (pp. 67-88). ANU Press.

Woodcock, J. (2017). Management. In Working the Phones: Control and Resistance in Call Centres (pp. 60-96). London: Pluto Press.

Wright, W. (1912). A Psychological definition of religion. The American Journal of Theology, 16(3), 385-409. 